\title{
THE EARNINGS AND SOCIAL SECURITY CONTRIBUTIONS OF DOCUMENTED AND UNDOCUMENTED MEXICAN IMMIGRANTS
}

Gary Burtless and Audrey Singer

CRR-WP 2011-2

Date Released: January 2011

Date Submitted: December 2010

\author{
Center for Retirement Research at Boston College \\ Hovey House \\ 140 Commonwealth Avenue \\ Chestnut Hill, MA 02467 \\ Tel: 617-552-1762 Fax: 617-552-0191 \\ http://crr.bc.edu
}

Gary Burtless holds the John C. and Nancy D. Whitehead Chair in Economic Studies at the Brookings Institution. Audrey Singer is a demographer at the Brookings Institution. The research reported here was performed pursuant to a grant from the U.S. Social Security Administration (SSA) funded as part of the Retirement Research Consortium (RRC). The opinions and conclusion expressed are solely those of the authors and do not represent the opinions or policy of SSA, any agency of the federal government, the RRC, the Brooking Institution, or Boston College.

(C) 2011, by Gary Burtless and Audrey Singer. All rights reserved. Short sections of text, not to exceed two paragraphs, may be quoted without explicit permission provided that full credit, including (C) notice, is given to the source. 


\title{
About the Center for Retirement Research
}

The Center for Retirement Research at Boston College, part of a consortium that includes parallel centers at the University of Michigan and the National Bureau of Economic Research, was established in 1998 through a grant from the Social Security Administration. The Center's mission is to produce first-class research and forge a strong link between the academic community and decision makers in the public and private sectors around an issue of critical importance to the nation's future. To achieve this mission, the Center sponsors a wide variety of research projects, transmits new findings to a broad audience, trains new scholars, and broadens access to valuable data sources.

\author{
Center for Retirement Research at Boston College \\ Hovey House \\ 140 Commonwealth Avenue \\ Chestnut Hill, MA 02467 \\ phone: 617-552-1762 fax: 617-552-0191 \\ e-mail: crr@bc.edu \\ crr.bc.edu
}

\section{Affiliated Institutions:}

The Brookings Institution

Massachusetts Institute of Technology

Syracuse University

Urban Institute 


\section{Abstract/Policy Abstract}

Using information supplied by immigrants interviewed by the Mexican Migration Project (MMP) we analyze the Social Security coverage of jobs held by legal and other-than-legal Mexican immigrants who work in the United States. Our analysis suggests that about half the Mexican-born migrants residing in the United States who are wage earners and heads of household earn their incomes in jobs that are not covered by Social Security. Since workers in uncovered jobs tend to earn below-average wages, their earnings account for less than half the wages earned by Mexican immigrants. Evidence from the MMP survey shows that Social Security coverage is higher among Mexican immigrants who are authorized to live in the United States than it is among undocumented Mexican immigrants. Coverage among working legal permanent residents is less than 75 percent, but the coverage rate among undocumented workers is even lower, about 25 percent. Based on annual earnings reports in the March CPS we estimate that in 2007 about 1.4 percent of all U.S. wages, or $\$ 87$ billion, was earned by Mexican immigrant heads of household. Our estimates imply that about 52 percent of this total was earned in Social-Security-covered jobs while the remainder, about \$41 billion, was earned in jobs not covered by Social Security. The MMP surveys show that only a small proportion of undocumented migrants report a change in their legal status that allowed them to live and work legally in this country. Two-thirds of legalizations occurred within five years of the enactment of the Immigration Reform and Control Act in 1986. In the absence of this kind of special legislation, only a small percentage of undocumented workers is likely to be granted permanent residency status in the future. Thus, the Social-Security-covered wages of most of the undocumented workers who earn them will never result in an increased claim for Social Security benefits. 


\section{Introduction}

MigRANTS TO THE UNITED STATES who are working in this country without legal authorization may nonetheless hold jobs in which they contribute to Social Security. Although many undocumented immigrants work off the books, others contribute to Social Security through payroll deductions. To avoid detection, undocumented immigrants may use false documents to get jobs and pay Social Security taxes to fictitious accounts (Smith, Kramer, and Singer 1996).

The payroll tax contributions of undocumented workers improve the short-term position of the Social Security trust funds. Since these workers are unlikely to claim benefits, it is doubtful their contributions will give rise to future Social Security payments unless there is a change in their legal status. The short-run gain in Social Security revenues from undocumented workers depends on the number of such workers, their average earnings, and the percentage of their earnings that are obtained in Social-Security-covered jobs. The longer term liability of the Social Security system to these immigrants depends on the fraction of them who eventually become legal permanent residents (LPRs) and become entitled to collect Social Security payments.

In this paper we examine the earnings of one group of undocumented workers, those arriving from Mexico. The Department of Homeland Security estimates that more than 60 percent of all unauthorized immigrants in the United States are from Mexico (Hoefer, Rytina, and Baker 2008). Another 12 percent are from economically similar sending countries in Central America, together comprising nearly three-quarters of all undocumented immigrants present in the United States. We attempt to estimate the percentage of undocumented Mexican workers who have earnings while in the United States and the fraction of their earnings that is derived from Social-Security-covered jobs. Our estimates are then applied to a nationally representative sample of Mexican immigrant workers to predict the amount of Social Security taxes collected from legal and undocumented Mexican workers. Using information from a unique bi-national survey, we also identify the migrant workers who eventually become LPRs. With this information we try to determine whether the workers who successfully adjust their status are likely to have earned Social-Security-covered wages before they became LPRs.

Our analysis is motivated by the following questions: To what extent do undocumented immigrants contribute to Social Security? What can we learn about transitions in legal status made by undocumented immigrants? Can we draw conclusions about these transitions and the 
likelihood that undocumented immigrants will become legal residents and potentially eligible for Social Security benefits?

The Immigration Reform and Control Act of 1986 (IRCA) played an important role in legalizing undocumented immigrants in the late 1980s and early 1990s, particularly in the case of immigrants from Mexico. IRCA provided the opportunity for a large number of undocumented immigrants to legalize under a program that ultimately provided legal status to more than three million immigrants by 1992. The law attempted to reduce the size of the population that was illegally residing in the United States through legalization of those who were undocumented and to impede further illegal immigration by establishing sanctions against employers for knowingly hiring unauthorized aliens and by increasing enforcement efforts. One presumed and desired labor market effect was that legalized immigrants would be more likely to enter into jobs in the formal sector and have taxes withheld from their pay after they legalized (Smith et al. 1996).

The impact of immigration on Social Security financing was recently highlighted in the 2008 Social Security Trustees’ Report. In that report the Trustees changed their earlier assumptions about other-than-legal immigrants' earnings and benefits. This revision had a large impact on the long run outlook for Social Security. Our paper sheds light on the short-run impact of undocumented workers on Social Security tax collections. It also examines whether workers who become LPRs have previously earned Social-Security-covered earnings, and hence are on the path to gaining eligibility for benefits. Both issues are important for considering the impact of undocumented immigrant flows on the Social Security trust fund.

\section{Data}

Mexican Migration Project survey. Our analysis is based on information collected in the Mexican Migration Project (MMP), an ethnographic survey of communities in Mexico that are expected to have at least some outmigration to the United States. ${ }^{1}$ Since 1987 the survey has collected information on Mexican residents both in Mexico and the United States. A total of 128 sending communities in Mexico have been surveyed. We use information from all but the first four communities surveyed, which includes all MMP interviews since 1987. In the early years of the survey about four to eight communities were surveyed each year, but in more recent years the approximate number of surveyed communities has ranged between two and five. MMP

\footnotetext{
${ }^{1}$ A brief introduction to the survey and its design philosophy can be found at URLs http://mmp.opr.princeton.edu/research/design-en.aspx and http://mmp.opr.princeton.edu/databases/studydesign-en.aspx (accessed November 3, 2010).
} 
interviewers randomly sample households in selected communities in Mexico during the winter, when seasonal migrants are likely to return to Mexico. Using information collected on the destinations of migrants who are current residents of the United States, the MMP staff also select some of the destination communities for face-to-face interviews with migrants. Mexican immigrants in the United States are then interviewed in those destination cities, and respondents supply the same kind of information obtained from people interviewed in Mexico. The entire MMP data file contains information on more than 7,200 household heads with immigration experience in the United States. We exclude from our analysis the small number of migrants whose most recent trip to the United States began in 1979 or an earlier year.

The MMP communities do not represent a random or strictly representative cross-section of Mexican places. However, they include a broadly representative cross-section of communities where out-migration is expected to occur. Nor is the MMP sample a random cross-section of Mexican migrants. It does not necessarily represent all migrants who returned to Mexico or all who continue to reside in the United States. It does, however, provide information about migrants' work experiences in the United States, including data on the Social Security coverage of their jobs.

The survey instrument includes questions on basic demographic information as well as details about their first and most recent trip to the United States. Household heads supply yearby-year information about border crossings and detailed information about the last trip made to the United States, including information about their employment, earnings, and utilization of social services. Respondents are asked whether Social Security and federal income taxes were paid on their U.S. earnings (Durand and Massey 2006). ${ }^{2}$ Interviewers also obtain some information about the legal status of migrants while in the United States.

The analysis that follows focuses on two kinds of information provided to interviewers, information on legal status during their stays in the United States and migrants' U.S. earnings and Social Security coverage of those earnings. The information in the MMP survey permits us to identify some Mexican migrants who become LPRs in the United States. By comparing these respondents with those who did not regularize their legal status we can ultimately compare workers of both statuses and their contributions to Social Security.

\footnotetext{
${ }^{2}$ It does this through two questions-one that asks about Social Security coverage during the last trip to the United States, and one that was integrated into the survey beginning in 1999 and asks about Social Security coverage for every life year. Considering the ambiguity of the first question, which does not specify at what points in the last visit earnings were covered by Social Security, we chose to use the latter question for our analysis.
} 
In our analysis we use life histories of the migrants. These provide information on their experience for every individual year that they are in the United States (we refer to these as "life years" or "person years"). In view of the timing of the MMP interviews as well as their retrospective character, we have far more reports covering migrants' U.S. experiences in the 1980s and early 1990s than we do for experiences that occurred after the mid-1990s. Among the interviews available for our study, about half were conducted in 1996 or an earlier year. Obviously, none of those interviews provide information on U.S. earnings in 1997 or later years, whereas many post-1996 interviews provide information about migration experiences that began or ended before 1996. This implies our data on Social Security coverage and legal status are more extensive for the 1980s and 1990s than they are for the more recent past (Figure 1).

Current Population Survey. In this paper we use estimates of immigrant workers' Social Security coverage status derived from the MMP surveys to predict Social Security coverage of immigrant workers who are interviewed in the Current Population Survey (CPS). The CPS collects monthly information on the labor force status of individuals in a sample of about 60,000 households. The basic goal of the survey is to track the number of adults who are employed, unemployed, and out of the labor force. The Annual Social and Economic Supplement (ASEC) to the CPS, conducted every March, obtains more detailed information about the prior year on respondents' work status, work hours, income sources, and income amounts, including wages earned during the previous calendar year. The ASEC, or March CPS, is the most widely used source of data on median income and earnings and the distribution of income and earnings in the United States.

Starting with the 1994 survey, the CPS questionnaire has asked respondents about household members' countries of birth. The interview does not ask immigrant respondents about their legal status or the legal status of other immigrants in the household, although it does ascertain the citizenship status of the foreign-born. Census interviewers do not ask whether workers in the household paid Social Security taxes on their earnings. The CPS interview contains a question about foreign-born respondents' year of entry into the United States. We use this information, as well as wage data and basic demographic information on age, gender, marital status, and educational attainment, to match the experiences of MMP respondents to those of Mexico-born CPS respondents who have similar earnings amounts. The imputation of Social Security coverage using this method allows us to make estimates of the amount of Social Security covered earnings attributed to CPS immigrant workers. 
Comparison of migrants in the CPS and MMP. All of our analysis focuses on MMP and CPS sample members who are identified as a "household head," generally the primary earner. An overwhelming percentage of the migrant household heads in the MMP are males (Donato et al. 2008). If each calendar year in which an MMP migrant spends part or all of the year in the United States is treated as a person year, about 95 percent of the person years after 1979 are associated with a male migrant. In contrast, 27 percent of Mexican immigrant household heads are female in the March CPS surveys for 1994 through 2009. In most cases the interview information in the MMP is provided by the migrant, but for one-third of our sample information about the migrant is supplied by another family member, ordinarily the spouse of the household head. ${ }^{3}$ Figures 2 and 3 display some basic information about the household heads included in our sample who were residents of the United States in 1993. We selected this year for closer analysis because it is a year in which many MMP sample members were U.S. residents and it is the first calendar year in which we can distinguish between the earned incomes of immigrants and the native born in the CPS. Figure 2 shows the age distribution of these residents. For purposes of comparison, the solid line in the figure shows the age distribution of Mexican immigrant household heads interviewed in the March 1994 CPS survey. To be included in the CPS tabulation, immigrant household heads were required to have wage and salary earnings in calendar year 1993. The household heads in the MMP are younger than the working Mexican heads of household in the CPS. The mean age in the MMP sample is just 33.6 years, and the median is 31. In the CPS sample the mean and median ages are four years older.

The schooling of immigrant household heads in the MMP sample is low, not only in relation to that of American residents more generally but also compared with that of Mexican immigrant household heads who were interviewed in the March CPS. Figure 3 displays the frequency distribution of educational attainment reported for MMP immigrant household heads and for Mexican immigrant household heads interviewed in the March 1994 CPS. As in Figure 2 the frequency distribution of MMP sample members is indicated by bars while that of Mexican immigrants interviewed in the CPS is displayed by the solid line. Sixty-seven percent of the MMP sample completed eight or fewer years of formal schooling versus only 49 percent of the Mexican immigrants represented in the March 1994 CPS. For purposes of comparison, just 4

\footnotetext{
${ }^{3}$ We conducted sensitivity analysis of our most important results to determine whether our findings are affected by inclusion of proxy respondents' interview information in our tabulations. We did not find any systematic impact of including this interview information. The results reported below therefore rely on information supplied by both migrants and proxy respondents for the migrants.
} 
percent of all U.S. resident workers had less than a $9^{\text {th }}$ grade education in 1994 . At the other end of the educational spectrum only 5 percent of the MMP sample had received any schooling beyond high school compared with 16 percent of the Mexican immigrant household heads in the March 1994 CPS. For the working U.S. population as a whole, 54 percent of the workforce had accumulated some schooling beyond high school in that year.

A large fraction of migrants in the MMP sample report relatively short stays in the United States. Using information on all entries into the United States by household heads between 1981 and 2008, for example, we estimate that only about half of border crossings into the United States result in a stay that lasts longer than one year. In deriving this estimate we count every entry by an individual MMP household head. If the person reports multiple border crossings between 1981 and 2008, we include every border crossing so long as the migrant's country of residence can be determined one year after entry into the United States. Many migrants report multiple border crossings, and all of their qualified trips are included when we estimate the percentage of crossings that result in a stay lasting at least one year. Not surprisingly, migrants whose residence in the United States extends beyond two or three years have a sharply lower chance of returning to Mexico over the next year compared with migrants who are still in the first year of a stay in the United States.

\section{Earned income and Social Security coverage in the MMP}

The MMP provides information about the jobs migrants hold when they are in the United States, though the precise information is more detailed in the case of jobs held during the migrant's most recent stay in the United States. In total the migrant household heads in our sample give us information about approximately 30,000 person years spent in the United States between 1981 and 2008. Since the goal of nearly all migrants is to improve their labor earnings by crossing the border, nearly all of them report gainful employment while in the United States. Migrants report being employed in 96.7 percent of the person years covered by the MMP interviews. About 44 percent of jobs are in manufacturing, 25 percent in agriculture, and 17 percent in personal or domestic services. The typical hourly wage, not surprisingly, is low. Among MMP migrants reporting wages in 1993 the average reported wage was \$8.36 per hour and the median wage was $\$ 7.14$ an hour. The federal minimum wage in that year was $\$ 4.25$ an hour, and 7 percent of MMP migrants reported earning a wage below that rate. Not surprisingly, wages tended to rise over time. Whereas in 1990 about half of MMP migrants in the United States earned less than $\$ 7.25$ an hour, by 2000 that fraction fell to a little more than one-third. 
By 2005 only 18 percent of MMP household heads living in the United States reported earning an hourly wage below $\$ 7.25$.

Interestingly, the wages reported by MMP migrants are not very different from those reported by Mexican immigrants in the March CPS. One quarter of wage earners in the CPS survey are asked to report their wages each month, and in most cases it is possible to calculate an hourly wage rate from their responses (Schmitt 2003). Figure 4 displays the wage distribution of MMP migrants who reported an hourly wage in 1993-1996 and compares it to the hourly wage distribution of Mexican immigrants who headed households and reported an hourly wage in the 1994-1997 March CPS interviews. ${ }^{4}$ The two wage distributions are remarkably similar. The average hourly wage in the MMP sample is just 3 percent higher than the hourly wage among Mexican immigrants in the March CPS surveys. MMP respondents are somewhat more likely to report very low and very high hourly wages compared with their counterparts in the CPS, but the differences are not large. The correspondence between the hourly wage distributions of U.S. residents in the MMP sample and Mexican immigrants interviewed in the CPS offers reason to believe the Social Security coverage of wages earned by the two populations may be similar.

Beginning in 1999 MMP respondents were asked whether the migrant paid Social Security taxes on wages earned during a given calendar year spent in the United States. Since the question was asked regarding all life years in which migrants earned a wage, it is possible to identify samples of MMP respondents who had Social-Security-covered wages and wages not covered by Social Security in each calendar year from 1980 to 2008. For more than 95 percent of the sample a valid answer was recorded for the Social-Security-coverage question. The response rate was higher when the question was posed directly to the migrant and was lower when the MMP interview was completed by a proxy respondent (typically the spouse of the migrant). Between 1980 and 2008 about 9,500 person years of U.S. labor market experience could be analyzed to determine whether Social Security taxes were paid on immigrants’ earnings. In those person years an MMP household head earned wages in the United States and reported whether or not Social Security taxes were withheld from earnings. MMP respondents report that in almost 40 percent of those years the migrants’ earnings were covered by Social Security.

\footnotetext{
${ }^{4}$ Respondents to the March CPS survey report their annual earnings for the previous calendar year, though they report an hourly wage for the job they hold at the time of the March survey. Because our statistical imputation of Social Security coverage matches wages reported by MMP migrants to CPS workers' calendar year earnings, it makes sense to compare wages in the 1993-1996 MMP sample to the hourly wages reported in the 1994-1997 March CPS surveys.
} 
MMP respondents also described their legal residency status during each trip to the United States. This permits us to classify the legal status of migrants during each person year of their residence. We divided migrants into three broad groups, legal permanent residents, legal temporary visa holders, and undocumented immigrants. ${ }^{5}$ The top panel in Table 1 shows what proportion of working migrants in each of these categories had Social-Security-covered jobs. The first column in the table shows the percentage of person-years reported by migrants in each of the designated groups. The total number of person years is simply the sum of calendar years between 1993 and 2008 that migrant household heads in the MMP sample were known to be residents of the United States. ${ }^{6}$ The most common status of migrants in the MMP sample is undocumented immigrant followed by legal permanent resident (LPR). ${ }^{7}$ Not surprisingly, permanent residents have the highest proportion of years with Social-Security-covered jobs. Among legal permanent residents who report whether their jobs are covered by Social Security, about seven in 10 say they hold a Social-Security-covered job. The proportions are far lower for workers with temporary visas and for undocumented workers. In the last group, migrants report they held Social-Security-covered jobs in less than a quarter of the years in which they earned wages in the United States. For all groups combined, migrants report paying Social Security taxes on jobs they held in 38 percent of the years they spent as workers in the United States.

Table 1 also displays information on Social Security coverage among other categories of migrants. In the middle panel of the table, we show how Social Security coverage varies depending on the period of time migrants have spent in the United States. We divide migrants’ person-year data into four categories - a stay that has so far lasted less than two years, a stay that has lasted for at least two years but less than five years, a stay that has lasted between five and eight years, and a stay that has lasted at least eight years. Note that an individual migrant who stays in the United States for several years will supply multiple person-year records. One or more of the records may show the migrant has been in the United States for less than two years, while others may show the same migrant has been in the country longer. More than two-thirds of the person-year records refer to migrants in the first five years of their stay in the United

\footnotetext{
${ }^{5}$ A small proportion of respondents declined to describe the residency status of the migrant.

${ }^{6}$ Our treatment of the data is similar to Riosmena (2004), who analyzed trends in return migration to Mexico after organizing the MMP data to permit tabulations of the person years that undocumented migrants spent inside and outside the United States. The information in Table 1 is derived from tabulations of migrants' person years in the period from 1993 through 2008, a period that overlaps with information available in the CPS files to determine respondents' immigrant status (see below).

${ }^{7}$ Legal permanent residents include a small number of naturalized U.S. citizens.
} 
States, and 44 percent refer to migrants in the first two years of a stay. Migrants are less likely to hold Social-Security-covered jobs early in a stay. Only 35 percent of migrants in their first two years of a stay report Social-Security-coverage on their jobs, while among migrants who have been in the country eight years or longer 58 percent report holding a Social-Security-covered job.

The bottom panel in Table 1 shows how Social Security coverage varies by the migrant's wage level. We have classified migrants in three wage groups depending on their relative wage rates within each calendar year of the observation period. Using the individual sample weights provided in the MMP file, we divided the weighted sample in each calendar year into thirds after ranking them according to their reported wage. We placed workers in the lowest third of the wage distribution into the "low earner" group, workers in the middle of the distribution into the "middle earner" group, and workers in the top third of the distribution into the "high earner" group. Slightly more than a quarter of working migrants did not report an hourly wage and consequently could not be classified. Not surprisingly, workers who earned the highest wages were the most likely to hold jobs covered by Social Security. Slightly more than half of them reported that Social Security taxes were withheld from wages but only about a third of workers in the lowest wage group reported Social Security coverage. The results in the bottom panel suggest that, while only 38 percent of MMP workers report paying Social Security taxes in a typical year, the percentage of total migrant earnings covered by Social Security is likely to be greater than 38 percent. This is because workers who earn above-average wages are more likely to hold jobs covered by Social Security.

\section{Imputations of Social Security coverage in the CPS files}

As noted above, the CPS questionnaire was expanded in 1994 to include questions on the citizenship status and country of origin of immigrants and their year of entry into the United States. Census Bureau interviewers do not ask respondents about the legal status of noncitizens. The March CPS interview contains retrospective information on adults' work experience and earnings in the previous year, so it is possible to distinguish between the earned incomes of native-born citizens, immigrant citizens, and immigrant noncitizens for all calendar years starting in 1993. It is not possible, however, to distinguish between noncitizens who are in the country legally and illegally. Our main interest in this part of the paper is not the legal status of immigrants, however, but the Social Security coverage of their wage earnings. Census interviewers do not ask CPS respondents whether they or other family members have paid Social 
Security taxes on their wages, so we must impute this information from another source. The information source we use is the MMP survey.

Methodology. Our basic procedure is to impute Social Security coverage onto CPS immigrant wage and salary workers using the responses of similar but randomly selected migrants in the MMP sample. Our imputation uses a statistical matching procedure known as cold decking. Cold decking is ordinarily used to impute values for a missing variable in a file using information from another survey in which the variable was ascertained. For the procedure to work, both survey files must contain one or more variables in common so that a statistical match can be performed. In a standard cold deck imputation, respondents in both survey files are stratified into cells defined by identical categorical variables. Within each cell, a donor (that is, an observation in the survey file with complete information) is randomly selected to represent each observation in the file that is missing the crucial variable. The procedure is usually carried out with the proviso that no donor can be selected more than a specified number of times. Once a donor and an observation with missing information are matched, the valid responses of the donor are copied over to the observation with missing information. In the event that a donor is not available in the exact cell in which the target observation is a member, the procedure advances to succeeding higher level cells until a suitable donor is found.

In our case, donors are randomly selected from appropriately defined cells in the MMP file to supply Social Security coverage information for immigrant working heads of household in the CPS file. We only matched CPS workers to MMP workers who reported whether their jobs were covered by Social Security. In performing the imputations, working household heads in the MMP and CPS were sorted by critical characteristics (or key variables) to ensure that the Social Security coverage of a MMP household head was matched to a similar wage earner in the March CPS. Our seven key matching variables include, in descending order of importance, gender, marital status, age, number of years since entry into the United States, basic education level, wage level, and specific schooling attainment level. ${ }^{8}$ Ideally, each eligible observation in the

\footnotetext{
${ }^{8}$ The key variable classifications are as follows: Gender - (a) male, (b) female; Marital status - (a) currently married, (b) not currently married; Age - (a) 16-24, (b) 25-34, (c) 35-44, (d) 45-54, (e) 55 and older; Years since entry into the U.S. - (a) less than 2 years, (b) between 2 and 4 years, (c) between 5 and 7 years,(d) 8 years or more; Basic education level - (a) less than 10 years of schooling, (b) 10 or more years of schooling; Wage - (a) low earner, (b) average earner, (c) high earner defined using hourly wage rates in the MMP and annual wage and salary earnings in the CPS file; Specific educational attainment (a) no schooling, (b) 1 to 4 years, (c) 5 or 6 years, (d) 7 to 9 years, (e) 10 to 12 years, and (e) more than 12 years of schooling. The hourly wage breaks and annual earnings breaks to define high, middle, and low earners were calculated separately in each calendar year to divide the weighted samples in that year into three equal-sized groups.
} 
CPS file would be randomly matched on all seven variables to a qualified donor observation from the MMP file. In some cases, however, it is impossible to find a donor observation that matches on all the key variables. In that case we relaxed the requirement that the target and donor observations have matching specific schooling attainment levels, and we attempted to find a MMP donor using the other six key variables. If a CPS observation could not be matched on those six key variables, we relaxed the requirement that the target and donor observations have matching wage levels. This procedure of successively relaxing the match requirements was followed until a MMP donor for each CPS worker was found.

In our implementation of cold-decking with the MMP and CPS files, we limited MMP donor records to be used no more than 50 times. Most MMP records were used fewer than five times, but there are some kinds of observations that occur much more frequently in the CPS than in the MMP due to the nature of their respective samples. In particular, it is relatively more common for Mexican immigrant heads of household in the CPS to report they have been in the United States for eight years or longer. In any given year of residence in the United States immigrants in the MMP are more likely to be in an early year of their stay. This difference reflects the nature of the samples for each survey, with the CPS representing more settled immigrants and the MMP representing more circular migrants. For CPS immigrants with lengthy residence in the United States it may therefore be difficult to find suitable donors in the MMP file. The success of our matching procedure for Mexican immigrant heads is shown in Table 2. The table shows the level of matching for each of the CPS observations. An observation with a match level of 1 is one that has been successfully matched to a MMP donor on all seven key variables. A match level of 2 indicates that the match was successful on the six most critical of the seven key variables. About 60 percent of CPS immigrants were matched on all seven key variables or all but one key variables. Only about 10 percent were matched on just two or three key variables.

The table contains summary information for CPS observations in two periods, 1993-2000 and 2001-2008. In the first period we matched MMP donor records to CPS respondents in the same calendar years. That is, a MMP donor record reflecting a migrant's labor market experience in, say, 1996 would be matched to a CPS immigrant who was reporting work experience and wage earnings for the same calendar year. Starting in 2001, however, the availability of MMP donor records declines (see Figure 1). We combined MMP person-year records from a number of years to create the donor pool to match CPS records for the years 
2001-2008. ${ }^{9}$ Because the donor pool contains a shrinking percentage of records from the most recent years, there is good reason for caution in interpreting the imputations for years after 2004. Even in those years, however, the imputations of Social Security coverage for CPS immigrant household heads are based on reasonably recent experiences of MMP respondents.

Results. Figure 5 shows the main results of our analysis of Social Security coverage in the CPS Mexican immigrant population. The migrants included in this analysis are wage and salary workers in the indicated year who are heads of household. Our results cover the span of years from 1993, when immigration status is first reported for CPS respondents, through 2007. The lower broken line shows the percentage of Mexican wage earners predicted to have SocialSecurity-covered wages. On average over the period we predict that slightly less than half of all wage earners in a given year have Social-Security-covered earnings. Slightly more than half have earnings but do not pay Social Security taxes on those earnings. The higher solid line in the chart shows the percentage of immigrants' total wage earnings in a year that is covered by Social Security. On average over the years from 1993 to 2007 our statistical matching procedure predicts that 54 percent of immigrants' wages were earned in Social-Security-covered jobs. Thus, as expected immigrant workers in better paying jobs were more likely to have Social Security taxes withheld from their pay. Of course this prediction means that 46 percent of the wages earned by Mexican immigrant workers were obtained in jobs where employers do not withhold payroll taxes from the worker's earnings.

Both measures displayed in Figure 5 show that Social Security coverage declined after 1993, but there was some recovery in coverage starting around 2000. The initial trend after 1993 may be traceable to the Immigration Reform and Control Act (IRCA), passed in 1986, which established a path toward legalization of status for undocumented workers who entered the United States before 1982 and then remained continuously in this country. The MMP sample contained a higher proportion of legal (temporary or permanent) residents in the early 1990s compared with more recent years. Some of these legal residents adjusted their residency status through the legalization provisions of IRCA. The change from illegal to legal status enabled some migrants to find Social-Security-covered jobs that might have been unattainable to

\footnotetext{
${ }^{9}$ For CPS immigrants in 2001, we created the MMP donor pool from person records covering 2000 and 2001. For 2002, we used MMP records from 2001-2002; for 2003, we used MMP records from 2001-2003; for 2004, we used MMP records from 2001-2004; for 2005, we used MMP records from 2000-2005; for 2006, we used MMP records from 2000-2006; for 2007, we used MMP records from 2000-2007; and for 2008, we used MMP records from 2001-2008.
} 
undocumented workers. After the mid-1990s fewer of the migrants entering the MMP sample were affected by the status adjustments made possible under IRCA.

Figure 6 shows the predicted fraction of immigrants' wages covered by Social Security in two different periods and in three different pay classes. Workers with low annual wages have the smallest predicted chances of being employed in Social-Security-covered jobs. Only about 40 percent of their wages are predicted to be earned in the Social-Security-covered sector between 1993 and 1999. We estimate that this fraction fell to 30 percent between 2000 and 2006. Coverage rates are predicted to be higher in the middle- and high-wage groups. In the middle-wage group the coverage rate was predicted to decline after 2000, though the estimated coverage rate remained unchanged among workers in the top third of the wage distribution. Thus, the predicted falloff in Social Security coverage over the analysis period was mainly concentrated among migrants who earned low wages in the United States. The precarious work situation of low wage immigrant workers likely accounts for much of the drop.

The validity of the estimates in Figures 5 and 6 depends on an assumption that is hard to evaluate. Our hypothesis in applying the statistical cold-deck imputation method is that the factors determining Social Security coverage in the MMP sample have identical or similar effects among Mexican immigrants interviewed in the CPS. Because the two samples are drawn in very different ways this assumption is unlikely to be completely true, but its accuracy is hard to evaluate without additional information about CPS respondents’ visa status and Social Security coverage. Since these characteristics are unavailable, we examine the sensitivity of our Social Security coverage predictions by estimating how they would vary if we expanded or narrowed the CPS sample in various ways.

The estimates shown in Figures 5 and 6 were obtained by making a statistical imputation of Social Security coverage to CPS respondents who were Mexican immigrants, who headed households, and who earned wages in one of the indicated years. We can narrow the CPS population in a way that makes it correspond more closely to the sample enrolled in the MMP. One way to do this is to focus on our coverage predictions for noncitizen Mexican immigrants. Relatively few MMP household heads are citizens, although a large proportion are legal permanent residents. We can restrict the CPS population even more narrowly by focusing on our predictions for noncitizen Mexican immigrants who have low levels of educational attainment. Our tabulations show that MMP household heads have even less schooling than Mexican immigrants who head households in the United States (Figure 3). Another way to examine the sensitivity of our estimates is to see how our estimates vary if statistical imputation 
is applied to a broader population than the one examined above, for example, to a sample that includes immigrants from countries with sending populations that are similar to Mexico’s. Such a population would include immigrants from Central America, who are similar to Mexican immigrants in many respects, including low income and poor educational qualifications (U.S. Congressional Budget Office 2005).

Figure 7 shows the total wage and salary income reported by these immigrant populations in the CPS files for 1993-2007. The earnings of the groups are measured as a percentage of the total wage and salary income reported by all CPS respondents. The largest population that we examine, which includes both Mexican and Central American immigrants, earned 1.2 percent of total wages reported in 1993 and slightly more than 1.8 percent of wages in 2007. When Central Americans' earnings are subtracted, these percentages fall to about 1.0 percent and 1.4 percent, respectively. If we only include the earnings of noncitizen Mexican immigrants, the counted earnings of Mexicans shrinks about a third in 1993 and by one-half in 2007, indicating that Mexican immigrants who become citizens account for a growing fraction of Mexican immigrant earnings over time. (This is partly because the proportion of Mexican immigrants who are U.S. citizens in the CPS increased over the analysis period.) However, if we exclude the earnings of Mexican noncitizen immigrants who have completed high school there is very little effect on noncitizens’ earnings. An overwhelming percentage of Mexican noncitizens’ wages is earned by immigrants who have low levels of schooling.

In Figure 8 we show the sensitivity of our Social Security coverage estimates to variation in the samples to which we apply our imputations. We show estimates for two periods, 19931999 and 2000-2006. There is surprisingly little variation in the estimates of Social Security coverage across the four population groups. As expected, the predicted coverage rate is lowest in the least skilled population, namely, noncitizen Mexican immigrants who have not completed high school. However, the predicted coverage rates are not much higher in the other three populations we examine. In all four populations Social Security taxes are predicted to be collected on less than $\$ 6$ out of every $\$ 10$ of immigrants' wage earnings. In the more recent period, 2000-2006, Social Security taxes were collected on only about \$5 out of every $\$ 10$ of CPS-reported wages. Assuming that our imputation strategy provides a valid method for inferring coverage rates, the estimates imply that Social Security taxes were not collected on about $\$ 53$ billion of wages earned by Mexican and Central American immigrant workers in 2006, or nearly half of the total wages they earned that year. 


\section{Changes in legal status and Social Security coverage}

Compared with other Mexican immigrants, undocumented Mexican workers are substantially less likely to earn wages in Social-Security-covered jobs. Our MMP tabulations imply that only about one quarter of undocumented Mexican workers earn covered wages during a typical year they reside in the United States (Table 1). If these tax-paying workers become legal permanent residents, their previous contributions to Social Security may help them eventually to become eligible for and receive a future pension, thereby reducing the surplus in the Trust Fund due to unclaimed contributions made by undocumented workers. However, it is usually difficult for undocumented immigrants to change their status to become legal residents. Furthermore, gaining legal status does not necessarily mean that formerly undocumented migrants can claim the previous earnings on which they have paid Social Security taxes, since many have made contributions under an invalid Social Security number.

Adjustment of status to legal permanent resident. Outside of the IRCA experience, which allowed many undocumented immigrants to legalize during the late 1980s and early 1990s, individuals have few ways to adjust their legal status under U.S. immigration law. ${ }^{10}$ In view of the meager legal opportunities to adjust status, how likely is it that a contributing undocumented worker will become a legal resident of the United States? Although it is not easy to answer this question solely with survey responses from the MMP, we can report some suggestive evidence. Starting in 1997 MMP respondents were asked in what year they legalized their residency status in the United States (allowing for the option that they never legalized). ${ }^{11}$ We have tabulated responses to this question to determine the frequency and timing of legalization.

${ }^{10}$ During the period under study, U.S. immigration law provided for preferential admission to legal permanent residence to aliens with close relatives (who were U.S. citizens or LPRs), those with desired skills, and those that qualified as refugees. Temporary workers with needed skills could also be sponsored by employers. Many Mexican immigrants simply did not qualify for admission nor are Mexicans eligible for refugee status. Many immigrants, including Mexicans, were in long queues waiting for familysponsored visas. It was not uncommon for individuals waiting for their green cards to come to the U.S. in advance, either with temporary visas or through surreptitious measures. Thus, while we do not know motivations for illegal migration of the MMP migrants under analysis here, nor the circumstances under which they legalized, we see a close association between MMP respondents reporting they legalized and the IRCA window of opportunity.

${ }^{11}$ It is not clear whether this question was intended to capture those who legalized under IRCA or any change from undocumented to a legal status. However, since this question was initiated in 1997, it offers a retrospective look at transitions to legal status well after IRCA legalizations came through. Thus, it may include responses that represent changes to legal status other than those granted through IRCA, but given the timing of the question, the majority of legalizations were due to IRCA. 
A total of slightly more than 2,100 respondents answered the question about legalization, and 17 percent reported that legalization had occurred. The earliest reported year of legalization was 1945, but about 93 percent of legalizations occurred in 1980 or a later year. Figure 9 shows the frequency distribution of legalizations that took place in 1997 or an earlier year. The striking feature of the distribution is the large proportion of all legalizations that occurred between 1986 and 1990, corresponding closely to IRCA. Fully two-thirds of all the reported legalizations took place within five years of the passage of IRCA, the law that established a path to legalization. Only a small number of legalizations occurred in any other year. It appears, however, that responses may be skewed toward the year immigrants applied for legalization and not necessarily when they received legal status. ${ }^{12}$ We believe that the cluster of legalizations between 1986 and 1989, shown in Figure 9, can be attributed to this response pattern.

To further explore the transition of undocumented immigrants to legal status, we looked at all those surveyed in the MMP who had at least one full trip after 1980 (rather than just those who were asked the legalization question beginning in 1997). Instead of looking at the individual people, though, we looked at the individual trips that they took, following each trip taken to the United States in order to examine the kinds of transitions that occurred. We defined three exclusive statuses_-legal permanent, legal temporary, and undocumented_-and tracked migrant status upon entry and for every year that a migrant remained in the United States. If a migrant left the United States, then this was considered the end of the trip and the person was no longer followed. In this way, we were able to track whether a change in status occurred and determine the relationship between the status change and the year in which the trip began. We focused on Mexicans entering the United States as undocumented migrants in order to see in how many cases an undocumented entry into the United States ended in the migrant's legalization.

We examine two sets of illegal entrants, those who entered the United States in 1985 and in 1990. Figure 10 shows annual transitions to legal status for all undocumented MMP migrants who entered the United States in those two years. ${ }^{13}$ For each successive year following migrants' year of entry, we note whether migrants adjust their status to legal permanent resident

12 IRCA passed in 1986 and was implemented in 1987, with a 1-year application period for temporary residence between May 1987 and May 1988 (Phase I). During Phase II, temporary resident aliens then applied for lawful permanent residence. In the MMP data we see a correspondence between reported legalizations and application for legalization (see Smith, Kramer, and Singer 1996).

13 We chose 1985 and 1990 for this exercise because of the proximity of those years to the IRCA legalization period. The first sample represents migrants who were in the United States prior to the implementation of the program while the second represents migrants who entered shortly afterwards. 
from undocumented. As noted, we do not track immigrants once they leave the United States, even if they later return. Thus, the number of tracked immigrants shrinks in succeeding years after the year of entry. We start with a cohort of 350 undocumented migrants who entered the United States in 1985 and 268 migrants who entered in 1990. The top chart in Figure 10 shows the timing of permanent residency attainment among undocumented workers who entered in 1985. The bottom chart shows the same transition pattern among undocumented workers who entered five years later in 1990. For each year after entry into the United States we show the percentage of original entrants who shift status from undocumented to legal permanent resident. By the ninth year after entry, 22 percent of undocumented workers entering in 1985 had converted their status to legal permanent residents. Just 3 percent of migrants entering in 1990 had made the same transition. Nearly all of the 1985 entrants who adjusted their status to legal permanent resident did so in the second, third, and fourth years after entry into the United States, that is, in 1987, 1988, and 1989, years that immediately followed passage of IRCA. Very few migrants who made an undocumented trip in 1990 adjusted status to permanent legal resident in comparable years after their entry into the United States. ${ }^{14}$

This example demonstrates that legalizations for the MMP cohort who entered the United States in 1985 occurred almost exclusively in the five-year period after IRCA was enacted. In contrast, very few undocumented workers who entered the country in 1990 ever became legal permanent residents. The contrasting experience of these two groups of entrants is puzzling in one respect. IRCA's requirements for application for legal status stipulated that immigrants establish that they entered the United States before January 1, 1982, and that they had resided continuously in the United States in an unlawful status for five years after that date. Thus, undocumented workers who entered the country in both 1985 and 1990 should have been ineligible for legalization under IRCA. However, it is widely acknowledged that eligibility restrictions were relaxed and inclusive measures were taken, especially toward the end of the IRCA application period, in large measure because of pressure from advocacy groups and the

${ }^{14}$ Part of the difference between migrants entering in 1985 and those entering in 1990 is due to the fact that the MMP interviews provide somewhat more follow-up information for the migrants who entered the U.S. in 1985. However, in the first three years after the two groups entered the U.S. this difference is unlikely to explain the difference in legalization rates in the two groups. Approximately 16 percent of the 1990 migrants did not provide information about their U.S. experiences after 1993, whereas less than 1 percent of 1985 migrants had missing data for the period that began three years after their entry. For this difference to explain the gap in three-year legalization rates, however, nearly all of the 1990 entrants with missing data would have had to become LPRs. Since this is extremely unlikely, we conclude that the legalization rate among 1990 entrants was far below the rate observed among migrants who entered in 1985. 
courts (Hagan 1994; Meissner and Papademetriou 1988). Moreover, the overwhelming majority of immigrants who applied for legal status were granted legalization (Smith et al. 1996).

We also examined the timing of all transitions to legal status that occurred on trips that began between 1981 and 2008. The majority of legal status changes occurred during trips that began in the 1980s. About 17 percent of all trips that began in the 1980s ended in legalization compared with the less than 1 percent of all trips that began between 1990 and 2008. Among undocumented workers in the MMP sample who recently entered the United States, only a small number legalized their status. Unless U.S. immigration law is reformed to permit more legalizations, only a very small fraction of undocumented workers can expect to regularize their status and eventually become eligible for Social Security benefits.

Social Security coverage of wages earned before and after legalization. For most of the MMP respondents who reported they had become legally entitled to remain in the United States we were able to determine whether they earned Social-Security-covered wages before their legal status changed. MMP respondents interviewed in 1999 and later years were asked both about whether legalization occurred and about the Social Security coverage of wages they earned in each year they resided in the United States. A total of 285 legalized immigrants provided information about the Social Security coverage of pre-legalization earnings. In this sample 37 percent reported they held a Social-Security-covered job during at least one year before legalization occurred; 63 percent did not report any Social-Security-covered jobs in the period before legalization. We interpret this to mean that nearly two-thirds of undocumented workers who receive legal authorization to remain in the United States did not have any Social-Securitycovered earnings when legalization occurred.

Table 3 sheds light on Social Security coverage in the undocumented population and in the population that eventually legalized its status. The information is derived from interview responses covering a total of 1,820 undocumented workers interviewed in the 1999-2008 MMP surveys. In the top panel of the table we show tabulations of the interviews conducted each year and the number of person years of U.S. residence reported in those surveys. We distinguish between the person years reported by migrants who have not become legal U.S. residents by the time of the survey, shown in column 2, and migrants who legalized their residency status by the time of the MMP interview, shown in column 3. The person years reported by the second group are further divided into person years of U.S. residence before the migrant's status was legalized (column 4) and person years after legalization occurred, including the year of legalization (column 5). The bottom panel shows the percent of person years for each group in which Social- 
Security-covered wages are reported. For example, of the 746 person years of U.S. residence reported by MMP interviewees in 1999 who did not become legal U.S. residents, SocialSecurity-covered wages were earned in just 81 (or 11 percent) of those person years. ${ }^{15}$

Given the modest sample sizes in each calendar year we are not surprised that Social Security coverage varies from year to year. The bottom row in the lower panel of Table 3 shows the sum of results for all the interviews from 1999-2009. Undocumented workers in the MMP sample who never legalized their residency status earned Social-Security-covered earnings in 28 percent of the years they reported residing in the United States. Migrants who eventually legalized their status earned Social-Security-covered wages in 58 percent of their years of U.S. residency. Interestingly, however, in years before their legalization, migrants in this second group earned covered wages in only about 32 percent of their years of (illegal) U.S. residence. This coverage ratio is about the same as the rate observed among migrants who never legalized their status. After MMP migrants became legal residents, they earned Social-Security-covered wages in 74 percent of their years in the United States. These results suggest that workers in the MMP sample earn Social-Security-covered wages in about 30 percent of the years they reside in the United States as undocumented workers. In year-by-year tabulations, the coverage rate is similar for undocumented workers regardless of whether they do or do not eventually legalize their U.S. residency status. However, once they do legalize, they are more likely to make Social Security contributions on their earnings.

These results are consistent with those of the Legalized Population Survey (LPS), a survey of immigrants who legalized under IRCA. Five years after legalization, 90 percent of all legalized workers (and 92 percent of Mexican workers) reported that their employer withheld Social Security and other taxes from their pay, signifying most legalized workers were working on-the-books (Smith et al. 1996).

Undocumented workers who earn Social-Security-covered wages are unlikely to become entitled to receive Social Security benefits on their contributions unless they first become legal U.S. residents. ${ }^{16}$ In view of the small fraction of undocumented immigrants in the MMP who receive legal authorization to remain in the United States, our evidence suggests that an

${ }^{15}$ Our tabulations are restricted to MMP respondents who indicated whether or not they paid Social Security taxes on their earnings. The small proportion of respondents who did not know or did not respond are excluded.

${ }^{16}$ Even if they do become legal residents it might be unlikely they will be able to straighten out their accounts to gain credit for what they contributed before obtaining legal status. 
overwhelming percentage of undocumented migrants who earn Social-Security-covered wages will probably not become legal U.S. residents or gain eligibility for Social Security. This conclusion would certainly change if the Congress and President adopted a new policy that established a path to legalization for undocumented workers and their immediate relatives.

\section{Conclusions}

An estimated 11 million immigrants live in the United States without legal authorization to do so (Passel and Cohn 2010). Many of these immigrants work, and some of them work in jobs covered by Social Security. Their Social Security taxes increase the OASDI Trust Fund and, at least temporarily, improve the solvency of the Social Security program. Using information supplied by Mexican migrants to the United States in the MMP survey we have analyzed the Social Security coverage of jobs held by legal and other-than-legal Mexican immigrants who work in the United States. Our analysis suggests that about half the Mexicanborn migrants residing in the United States who are wage earners and heads of household earn their incomes in jobs that are not covered by Social Security. Since workers in uncovered jobs tend to earn below-average wages, their earnings constitute less than half the wages earned by Mexican immigrants. Over the period from 1993 to 2007 we estimate that approximately 53 percent to 56 percent of the immigrant wages we analyze were earned in Social-Security-covered jobs. Over this analysis period we believe Social-Security-coverage of Mexican immigrant earnings has probably declined modestly. One possible reason for the decline is that the proportion of legal residents in the Mexican immigrant population has declined. Many undocumented Mexican immigrants became legal residents of the United States as a result of IRCA, but these legalized residents became a smaller proportion of the Mexican immigrant population over time as new waves of undocumented workers entered the country after 1990. Evidence from the MMP survey clearly shows that Social Security coverage is higher among Mexican immigrants who are authorized to live in the United States than it is among undocumented Mexican immigrants. Even though Social Security coverage among working legal permanent residents is less than 75 percent, the coverage rate among undocumented workers is even lower, about 25 percent.

Based on annual earnings reports in the March CPS we estimate that about 1.4 percent of all U.S. wages, or \$87 billion, were earned by Mexican immigrant heads of household in 2007. Our estimates imply that about 52 percent of this total was earned in Social-Security-covered jobs while the remainder, about $\$ 41$ billion, was earned in jobs not covered by Social Security. 
If our estimates can be extended to a broader immigrant population that includes Central American as well as Mexican heads of household, total immigrant earnings would account for 1.8 percent of all U.S. wages, or $\$ 112$ billion. Of this total we estimate that 53 percent was earned in Social-Security-covered employment and 47 percent in jobs not covered by the Social Security system.

The MMP surveys provide some information about changes in the legal status of Mexican immigrants who either entered or stayed in the United States without legal authorization. Only a small proportion of these migrants report a change in their legal status that allowed them to live and work legally in this country. Two-thirds of these changes in legal status occurred within five years of IRCA's enactment, implying that an overwhelming share of the legalizations observed in the MMP sample were traceable to that one-time change in the standard for admitting undocumented migrants to permanent residency status. In the absence of this kind of special action, only a small percentage of undocumented workers are likely to be granted permanent residency status in the future. Thus, the Social-Security-covered earnings of most of the undocumented workers who earn them will never result in an increased claim for Social Security benefits. 


\section{References}

Donato, Katharine M., Chizuko Wakabayashi, Shirin Hakimzadeh, and Amada Armenta. 2008. "Shifts in the Employment Conditions of Mexican Migrant Men and Women: The Effect of U.S. Immigration Policy.” Work and Occupations. Vol 35, No. 4 (November) 462495.

Durand, Jorge, and Douglas S. Massey, eds. 2006. Crossing the Border: Research from the Mexican Migration Project (New York: Russell Sage).

Hagan, Jacqueline Maria. 1994. Deciding to Be Legal: A Maya Community in Houston. (Philadelphia, PA: Temple University Press).

Hoefer, Michael, Nancy Rytina, and Bryan C. Baker, 2008. "Estimates of the Unauthorized Immigrant Population Residing in the United States: January 2008.” (Washington, DC: Department of Homeland Security, Office of Immigration Statistics).

Meissner, Doris, and Demetrious Papademetriou. 1988. The Legalization Countdown: A Third Quarter Assessment. (Washington: Carnegie Endowment for International Peace).

Passel, Jeffrey S. and D’Vera Cohn, 2010. “U.S. Unauthorized Immigration Flows Are Down Sharply Since Mid-Decade.” (Washington, DC: Pew Hispanic Center).

Riosmena, Fernando. 2004. "Return Versus Settlement among Undocumented Mexican Migrants 1980 to 1996.” Jorge Durand and Douglas S. Massey, eds., Crossing the Border: Research from the Mexican Migration Project (New York: Russell Sage).

Schmitt, John. 2003. "Creating a Consistent Hourly Wage Series from the Current Population Survey’s Outgoing Rotation Group, 1979-2002.” Working paper. (Washington, DC: Center for Economic and Policy Research).

Smith, Shirley J., Roger G. Kramer, and Audrey Singer. 1996. "Characteristics and Labor Market Behavior of the Legalized Population Five Years Following Legalization.” (Washington, DC: U.S. Department of Labor).

U.S. Congressional Budget Office. 2005. “The Role of Immigrants in the U.S. Labor Market.” (Washington, DC: U.S. Congressional Budget Office). http://www.cbo.gov/ftpdocs/68xx/doc6853/1110-Immigration.pdf 
Table 1. Social Security Coverage of Migrants' Jobs in the MMP Sample, 1993-2008

\begin{tabular}{|c|c|c|c|c|c|c|}
\hline \multirow[b]{2}{*}{ Category of migrant } & & \multirow{2}{*}{$\begin{array}{c}\text { Percent of } \\
\text { person- } \\
\text { years } \\
\end{array}$} & \multicolumn{4}{|c|}{$\begin{array}{l}\text { Earnings covered by social } \\
\text { security? }\end{array}$} \\
\hline & & & Yes & No & Unknown & Total \\
\hline \multicolumn{7}{|c|}{ Migrants' U.S. residency status } \\
\hline Legal permanent resident & & 29 & 69 & 28 & 3 & 100 \\
\hline Legal temporary resident & & 9 & 38 & 61 & 1 & 100 \\
\hline Undocumented immigrant & & 61 & 24 & 72 & 4 & 100 \\
\hline \multirow[t]{2}{*}{ Unknown } & & 1 & 12 & 59 & 29 & 100 \\
\hline & Total & 100 & 38 & 58 & 3 & 100 \\
\hline \multicolumn{7}{|c|}{ Length of migrant's stay in U.S. } \\
\hline Less than 2 years & & 44 & 35 & 62 & 3 & 100 \\
\hline 2 to 4 years & & 24 & 31 & 66 & 3 & 100 \\
\hline 5 to 8 years & & 15 & 38 & 58 & 5 & 100 \\
\hline \multirow[t]{2}{*}{ More than 8 years } & & 17 & 58 & 38 & 3 & 100 \\
\hline & Total & 100 & 38 & 58 & 3 & 100 \\
\hline \multicolumn{7}{|l|}{ Migrants' hourly wage in U.S. } \\
\hline Low earner & & 27 & 34 & 64 & 2 & 100 \\
\hline Middle earner & & 26 & 42 & 55 & 3 & 100 \\
\hline High earner & & 21 & 51 & 48 & 2 & 100 \\
\hline \multirow[t]{2}{*}{ Unknown wage } & & 27 & 30 & 64 & 6 & 100 \\
\hline & Total & 100 & 38 & 58 & 3 & 100 \\
\hline
\end{tabular}

Source: Authors' tabulations of MMP files as explained in text. 
Table 2. Statistical Matching Levels for CPS Mexican Immigrant Wage

Earners, 1993-2008

\begin{tabular}{|c|c|c|c|c|c|c|c|}
\hline Years & Level & $\begin{array}{c}\text { Number of } \\
\text { observations }\end{array}$ & $\begin{array}{c}\text { Percent of } \\
\text { observations }\end{array}$ & Years & Level & $\begin{array}{c}\text { Number of } \\
\text { observations }\end{array}$ & $\begin{array}{c}\text { Percent of } \\
\text { observations }\end{array}$ \\
\hline \multirow[t]{8}{*}{2000} & 1 & 4,797 & $44 \%$ & $\begin{array}{l}2001- \\
2008\end{array}$ & 1 & 7,625 & $43 \%$ \\
\hline & 2 & 1,775 & $16 \%$ & & 2 & 2,644 & $15 \%$ \\
\hline & 3 & 2,194 & $20 \%$ & & 3 & 3,645 & $21 \%$ \\
\hline & 4 & 1,243 & $11 \%$ & & 4 & 1,710 & $10 \%$ \\
\hline & 5 & 599 & $5 \%$ & & 5 & 1,878 & $11 \%$ \\
\hline & 6 & 417 & $4 \%$ & & 6 & 236 & $1 \%$ \\
\hline & 7 & 0 & $0 \%$ & & 7 & 0 & $0 \%$ \\
\hline & Total & 11,025 & $100 \%$ & & Total & 17,738 & $100 \%$ \\
\hline
\end{tabular}

Source: Authors' tabulations of MMP and 1994-2008 March CPS files as explained in text. 
Table 3. Social Security Coverage of Migrants' Earnings before and after Legalization, by Year of MMP Interview

\begin{tabular}{|c|c|c|c|c|c|}
\hline \multirow[b]{2}{*}{$\begin{array}{c}\text { Year of } \\
\text { MMP } \\
\text { intervie } \\
\mathrm{w} \\
\end{array}$} & \multirow[b]{2}{*}{$\begin{array}{l}\text { Number of } \\
\text { MMP } \\
\text { interviews } \\
(1) \\
\end{array}$} & \multirow[b]{2}{*}{$\begin{array}{c}\text { Migrants } \\
\text { who never } \\
\text { become } \\
\text { LPRs } \\
(2) \\
\end{array}$} & \multicolumn{3}{|c|}{ Migrants who become LPRs } \\
\hline & & & $\begin{array}{l}\text { All person } \\
\text { years in the } \\
\text { U.S. } \\
(3)\end{array}$ & $\begin{array}{c}\text { Person } \\
\text { years } \\
\text { before } \\
\text { legalization } \\
(4) \\
\end{array}$ & $\begin{array}{c}\text { Person years after } \\
\text { legalization } \\
(5) \\
\end{array}$ \\
\hline & & \multicolumn{4}{|c|}{ Total number of person years as U.S. resident } \\
\hline 1999 & 215 & 746 & 784 & 323 & 461 \\
\hline 2000 & 213 & 701 & 687 & 249 & 438 \\
\hline 2001 & 234 & 832 & 375 & 118 & 257 \\
\hline 2002 & 178 & 686 & 132 & 39 & 93 \\
\hline 2003 & 159 & 520 & 420 & 221 & 199 \\
\hline 2004 & 170 & 721 & 127 & 40 & 87 \\
\hline 2005 & 70 & 221 & 296 & 66 & 230 \\
\hline 2006 & 152 & 550 & 373 & 125 & 248 \\
\hline 2007 & 210 & 727 & 508 & 222 & 286 \\
\hline 2008 & 112 & 406 & 273 & 100 & 173 \\
\hline 2009 & 107 & 522 & 64 & 17 & 47 \\
\hline \multirow[t]{2}{*}{ All years } & 1,820 & 6,632 & 4,039 & 1,520 & 2,519 \\
\hline & & \multicolumn{4}{|c|}{$\begin{array}{c}\text { Percent of total person years in which migrant had } \\
\text { social-security-covered earnings }\end{array}$} \\
\hline 1999 & 215 & 11 & 50 & 8 & 79 \\
\hline 2000 & 213 & 19 & 45 & 13 & 64 \\
\hline 2001 & 234 & 37 & 64 & 63 & 65 \\
\hline 2002 & 178 & 24 & 46 & 44 & 47 \\
\hline 2003 & 159 & 27 & 68 & 48 & 90 \\
\hline 2004 & 170 & 35 & 66 & 55 & 71 \\
\hline 2005 & 70 & 49 & 86 & 44 & 99 \\
\hline 2006 & 152 & 13 & 49 & 13 & 67 \\
\hline 2007 & 210 & 35 & 67 & 55 & 77 \\
\hline 2008 & 112 & 34 & 47 & 31 & 55 \\
\hline 2009 & 107 & 35 & 81 & 29 & 100 \\
\hline All years & 1,820 & 28 & 58 & 32 & 74 \\
\hline
\end{tabular}

Note: The sample is restricted to respondents who indicated whether their earnings were covered by social security. When no response was given to this question, the observation was excluded from the tabulation.

Source: Authors' tabulations of MMP files as described in text. 
Figure 1. Time Profile of U.S. Immigration Experience among Household Heads in the MMP Sample, 1980-2009

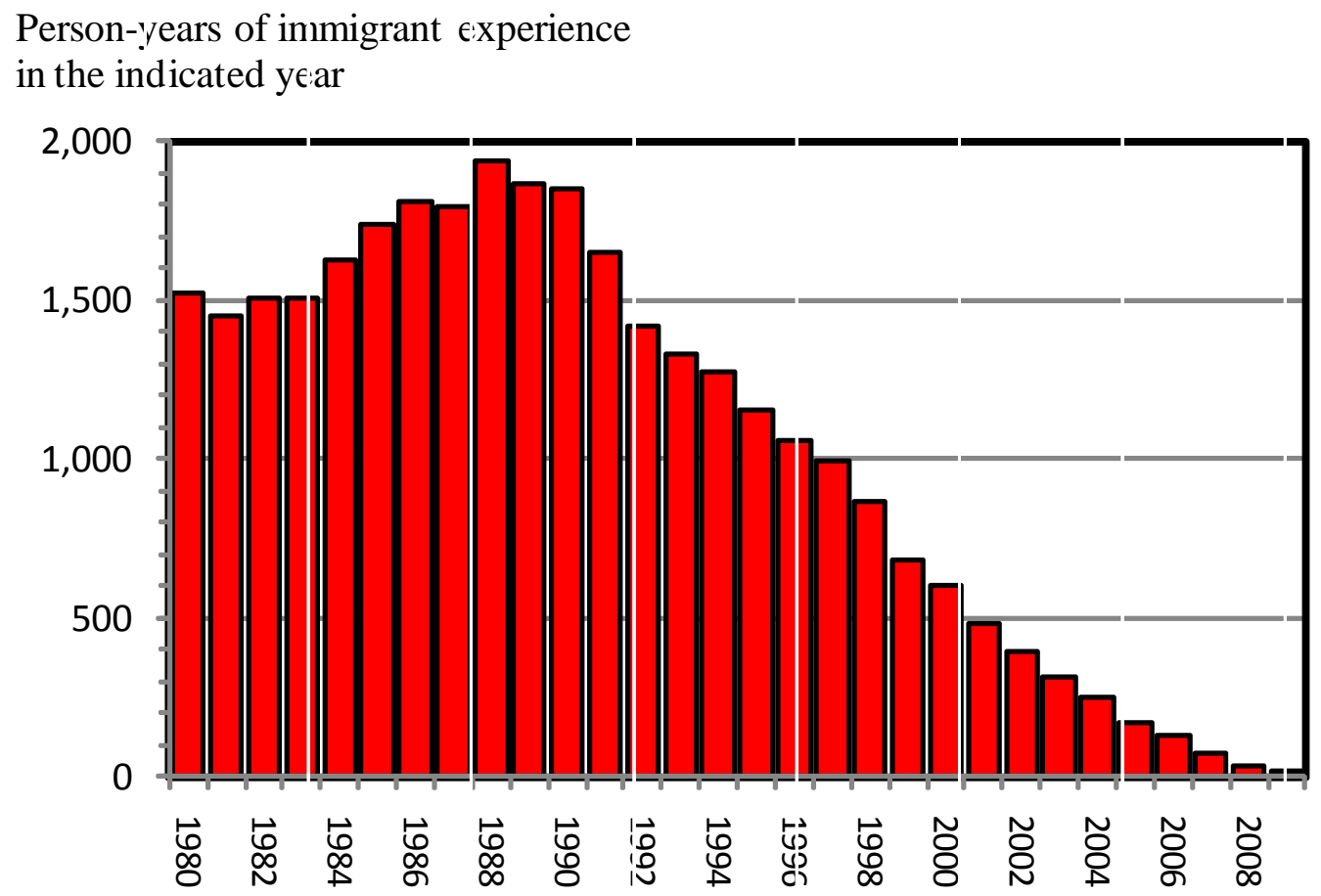

Source: Authors' tabulations of MMP data files. 
Figure 2. Age Distribution of Mexican Immigrant Household Heads in the MMP and CPS, 1993-1994

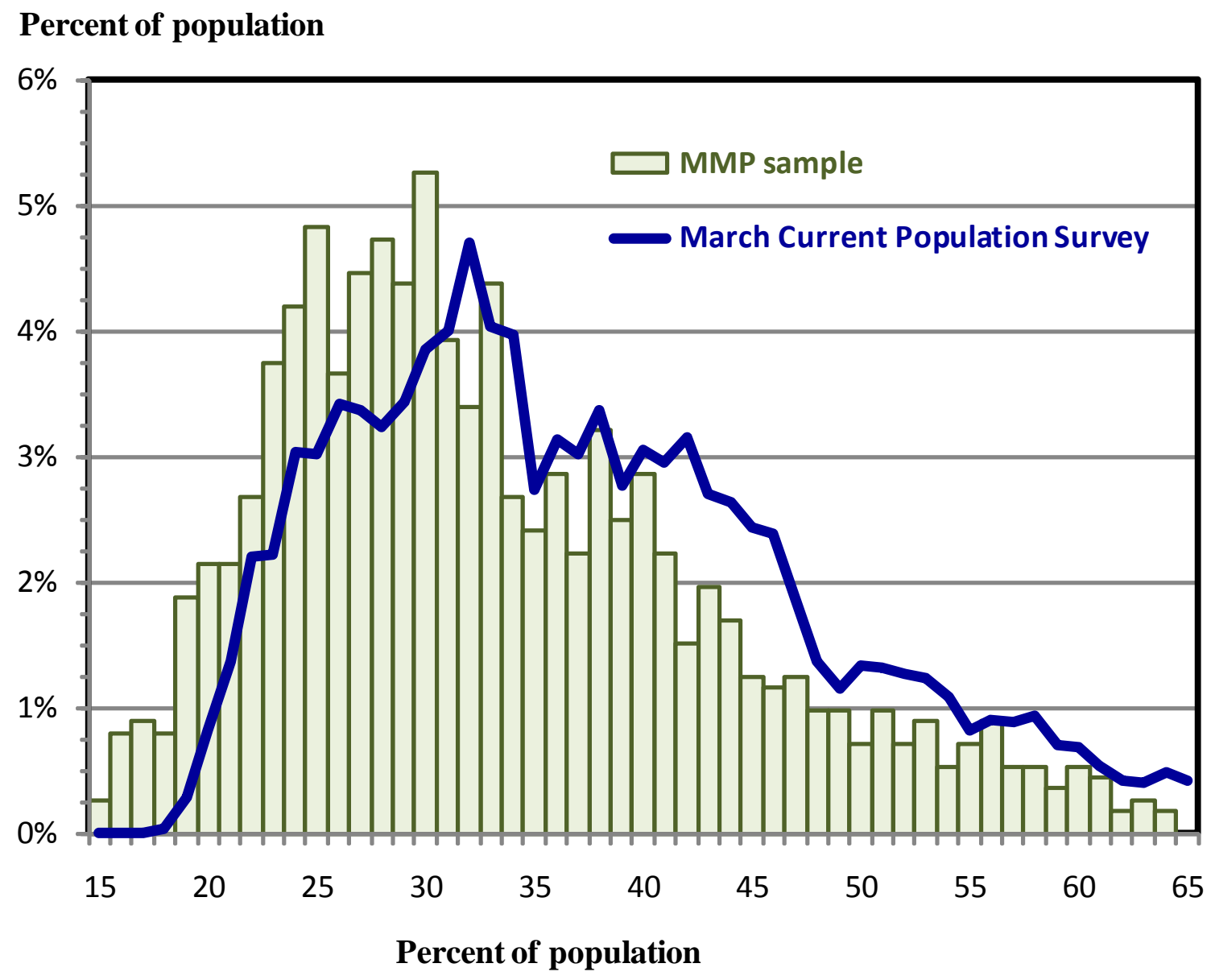

Source: Authors' tabulations of MMP and 1994 March CPS files. 
Figure 3. Educational Attainment of Mexican Immigrant Household Heads in the MMP and CPS, 1993-1994

Percent of population

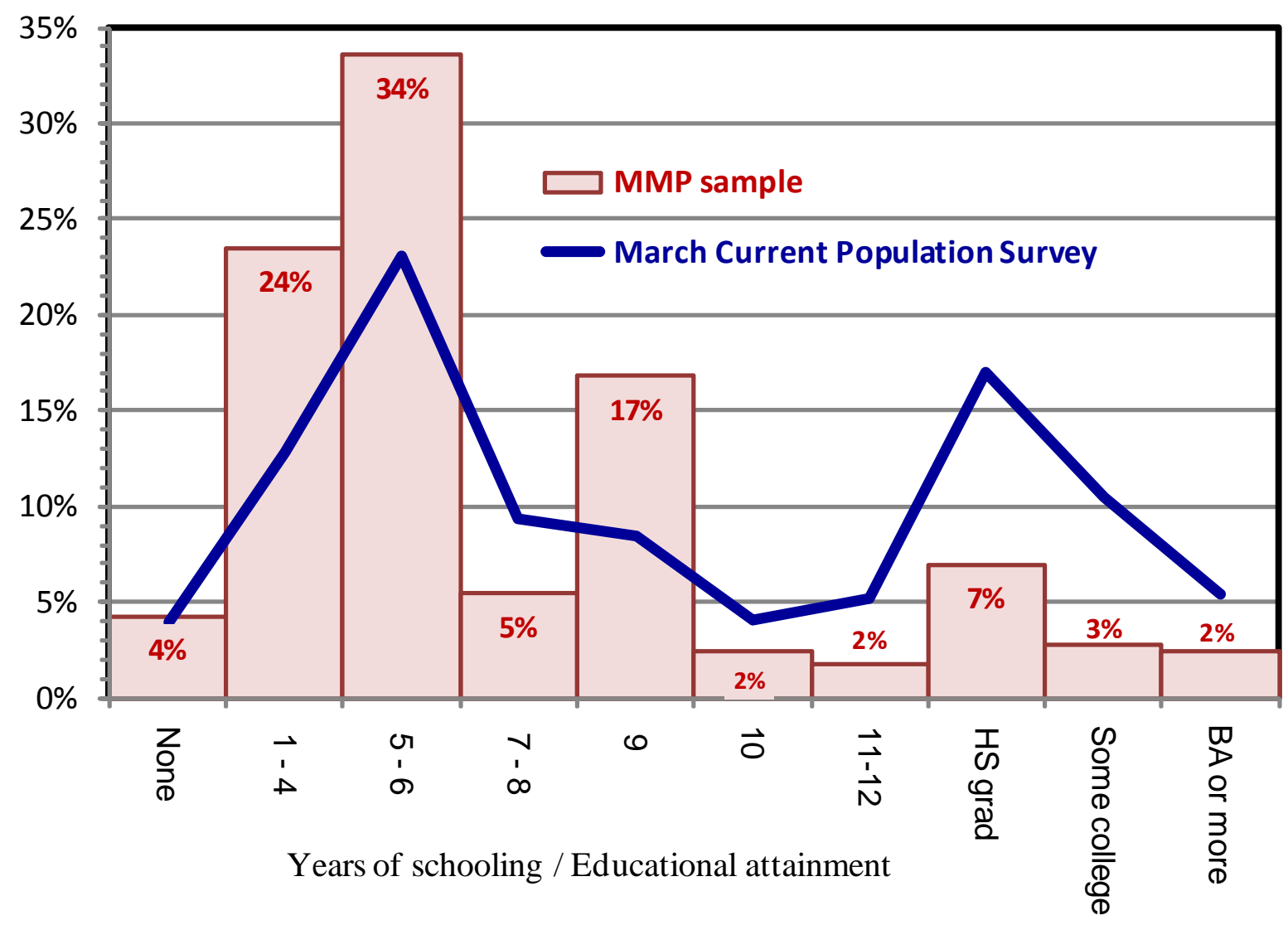

Source: Authors' tabulations of MMP and 1994 March CPS files. 
Figure 4. Wage Distribution of Mexican Immigrant Household Heads in the MMP and CPS, 1993-1997

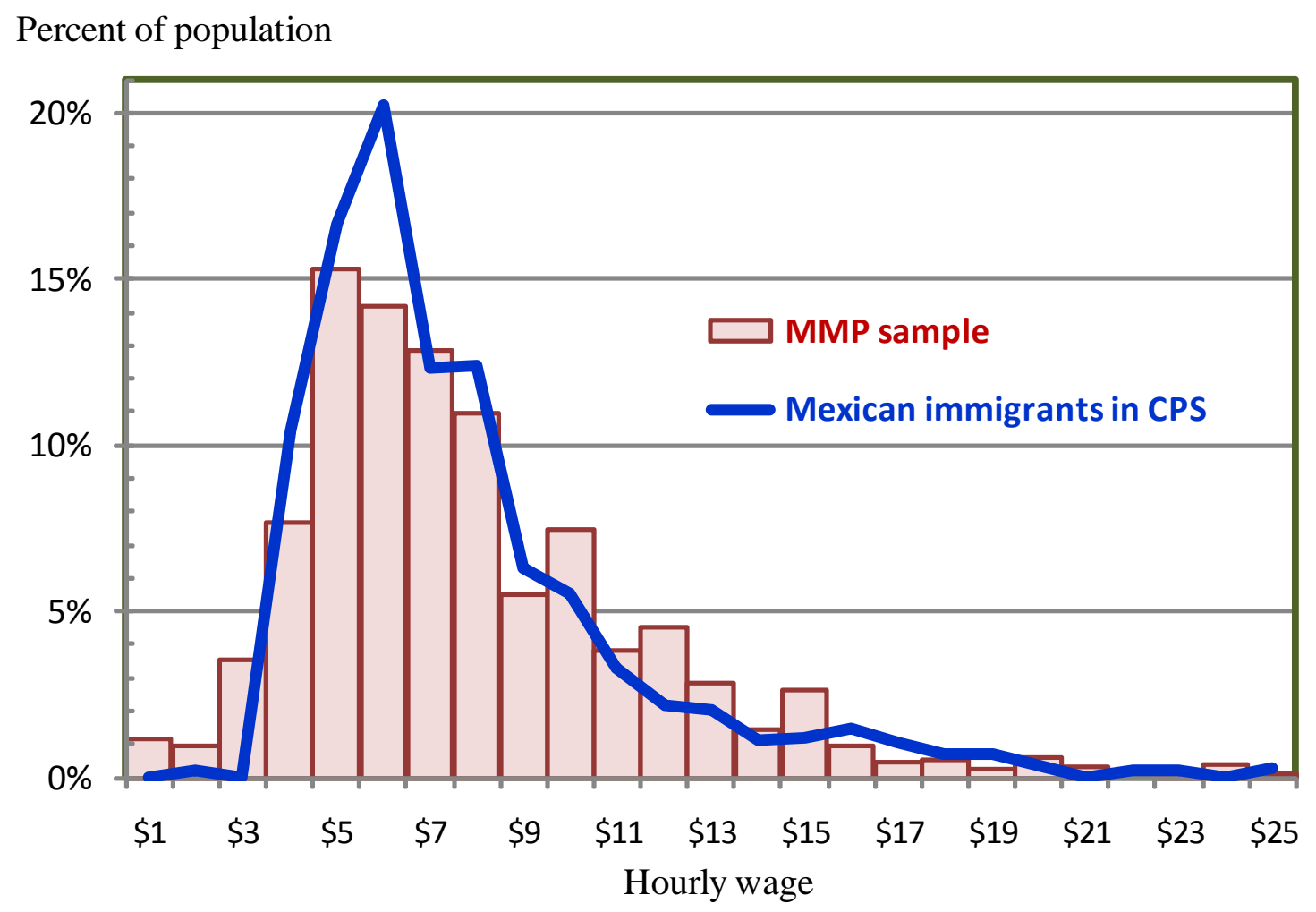

Source: Authors' tabulations of MMP and 1994-1997 March CPS files. 
Figure 5. Predicted Percent of Mexican Immigrant Workers and Wages Covered by Social Security, 1993-2007

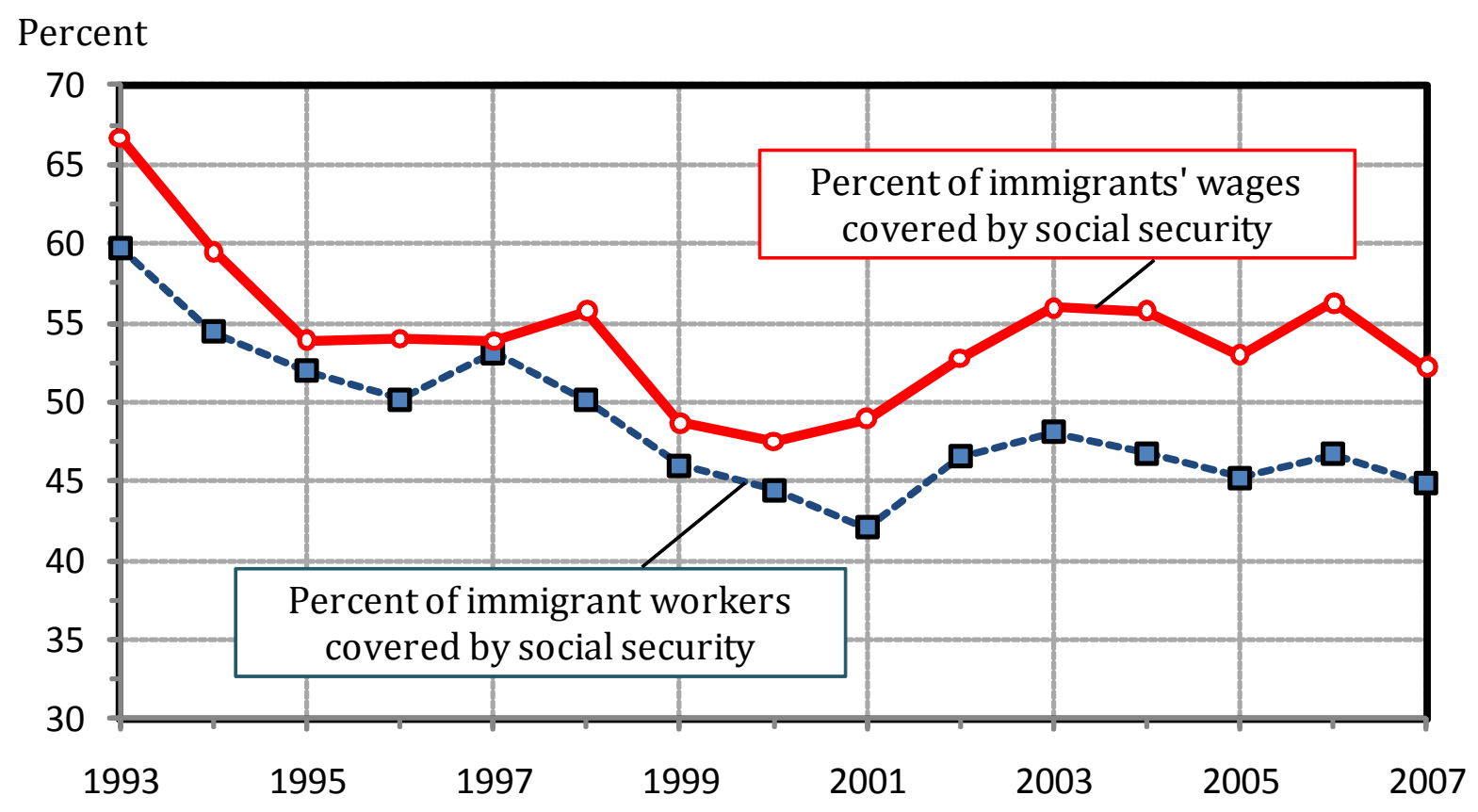

Source: Authors' tabulations of MMP and 1994-2008 March CPS files as explained in text. 
Figure 6. Predicted Percent of Mexican Immigrant Workers' Wages Covered by Social Security by Wage Level, 1993-2006

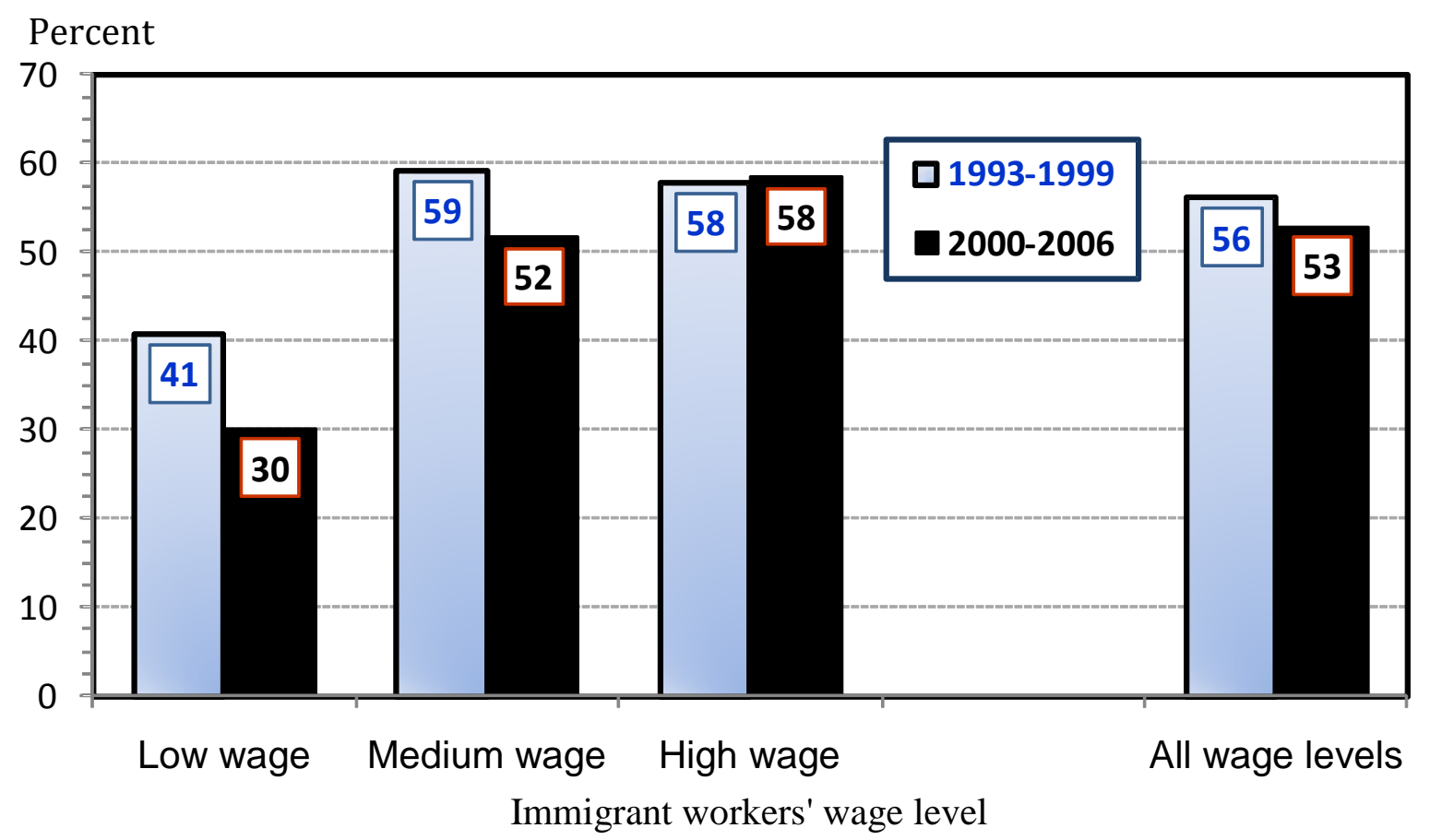

Note: "Low", "medium", and "high" wages are defined in reference to Mexican immigrants' annual wages rather than in relation to the overall U.S. earnings distribution. One-third of immigrant earners

Source: Authors' tabulations of MMP and 1994-2008 March CPS files as explained in text. 
Figure 7. Immigrants' Annual Wages in March CPS as a Percent of All Workers' Annual Wages, 1993-2007

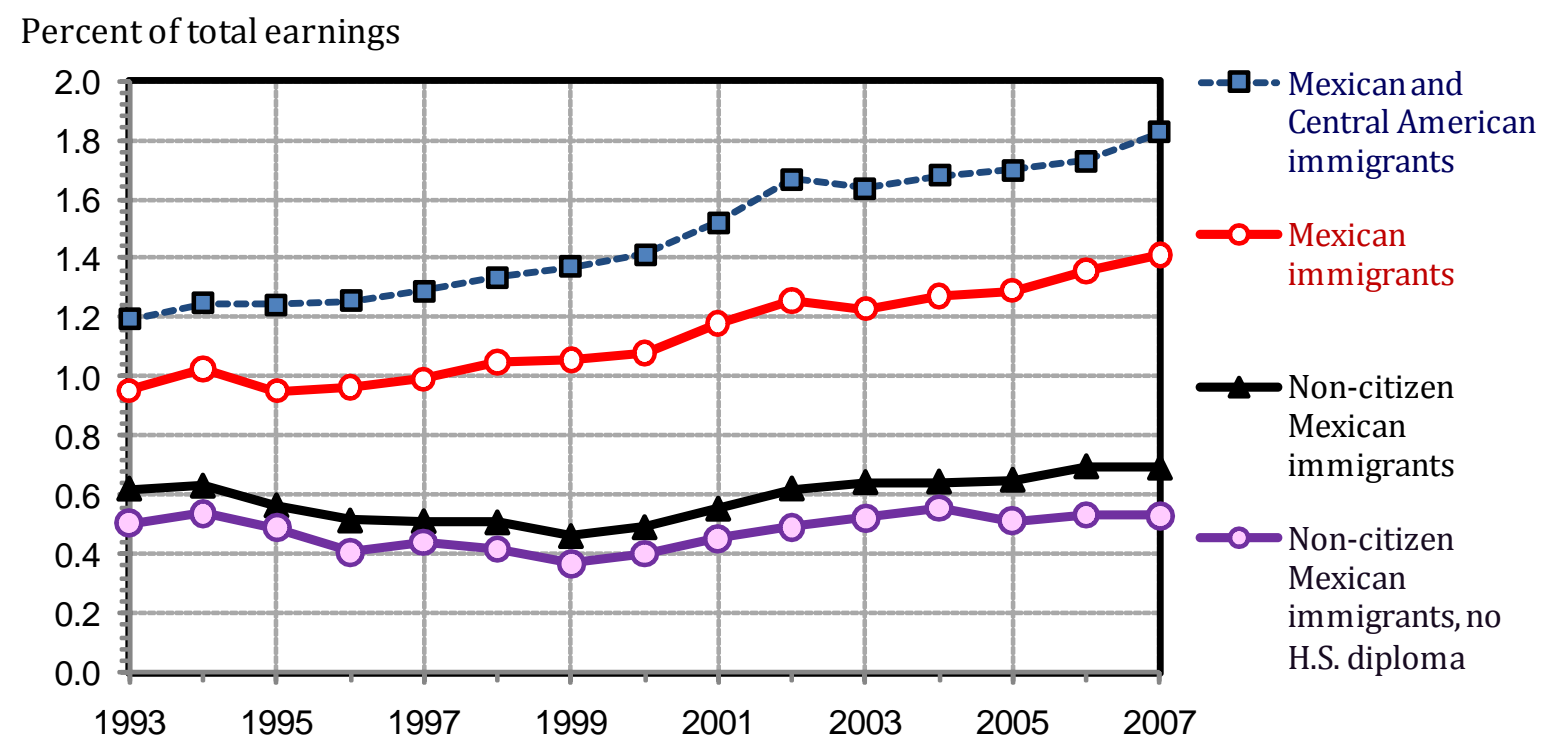

Source: Authors' tabulations of 1994-2008 March CPS files. 


\section{Figure 8. Predicted Percent of Workers' Wages Covered by Social Security}

across Different Immigrant Groups, 1993-2006

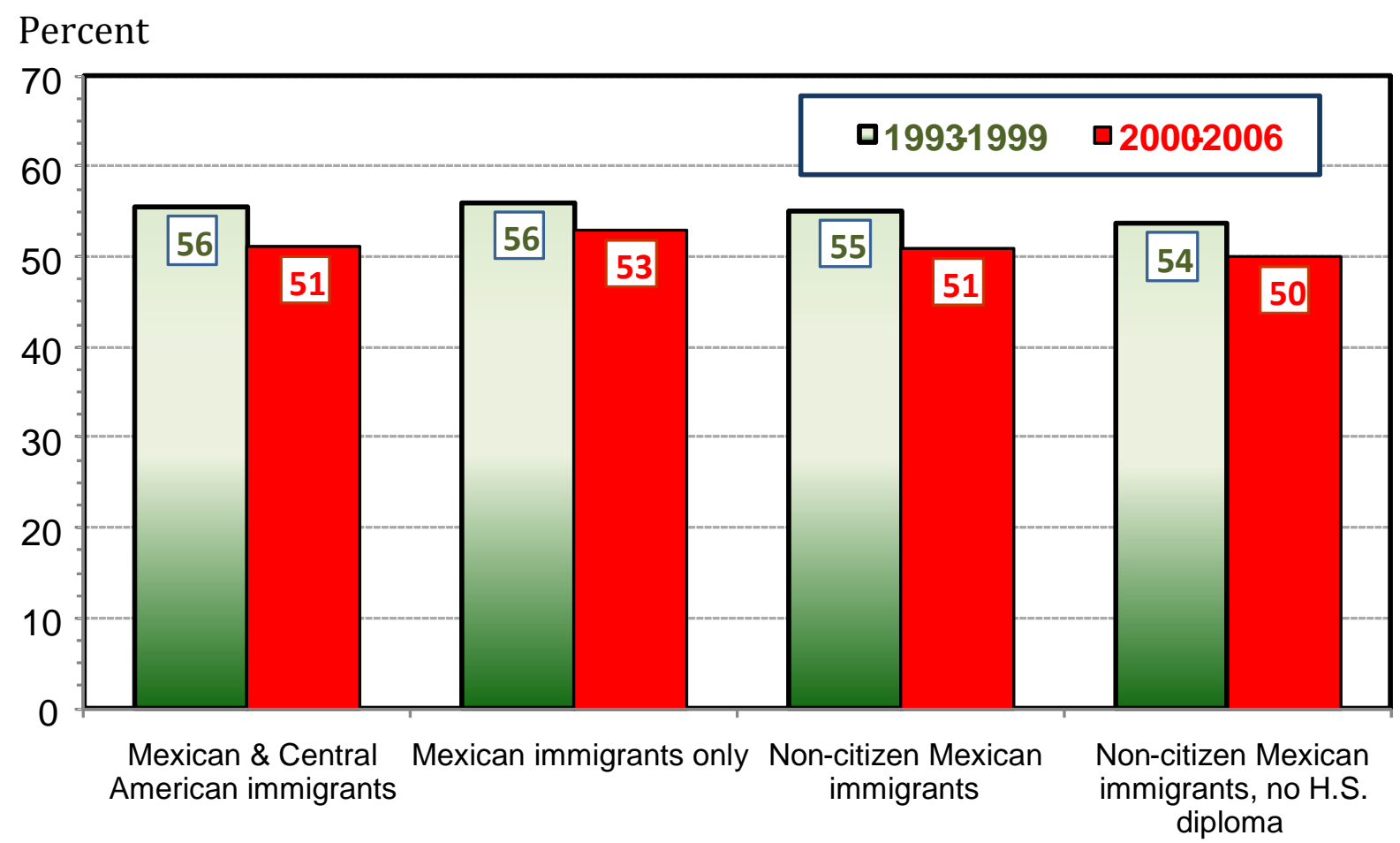

Source: Authors' tabulations of MMP and 1994-2008 March CPS files as explained in text. 
Figure 9. Frequency Distriubution of Reported Year of Legalization in the MMP Sample

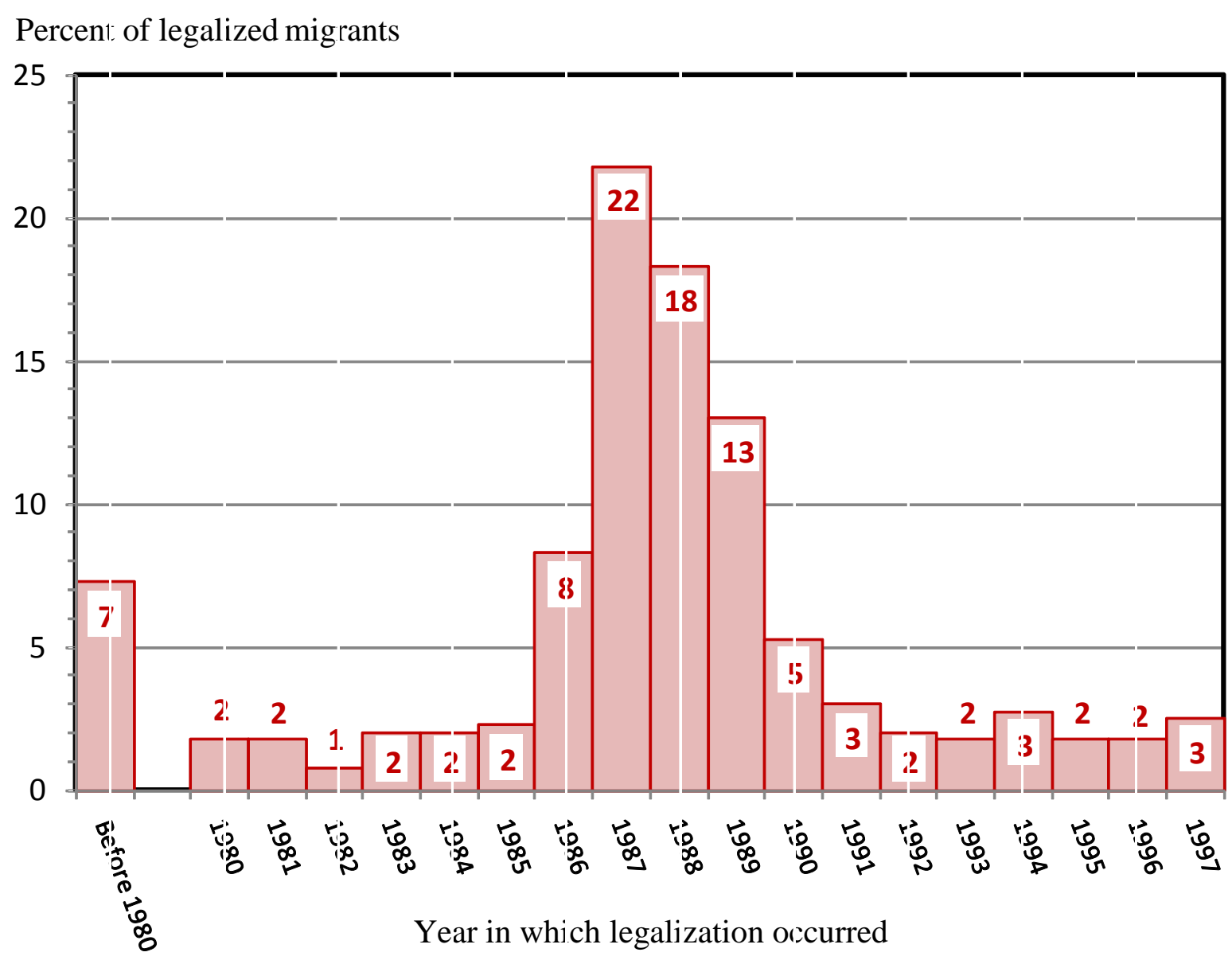

Note: MMP sample consists of 339 immigrants who report they became legal U.S. residents before 1998.

Source: Authors' tabulations of MMP files. 
Figure 10. Transitions of Undocumented Workers to Legal Permanent Resident Status by Year of Entry into the United States

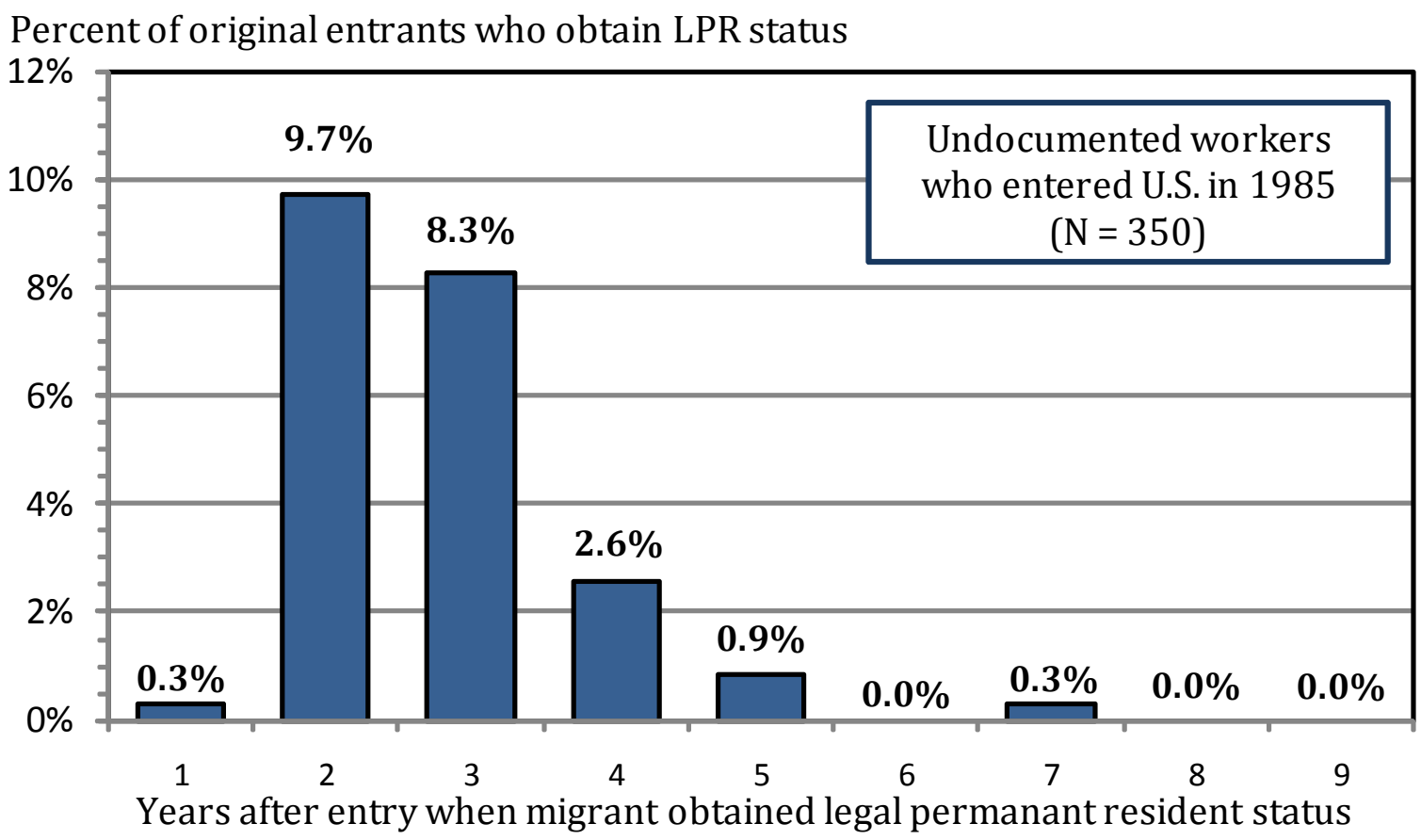

Percent of original entrants who obtain LPR status

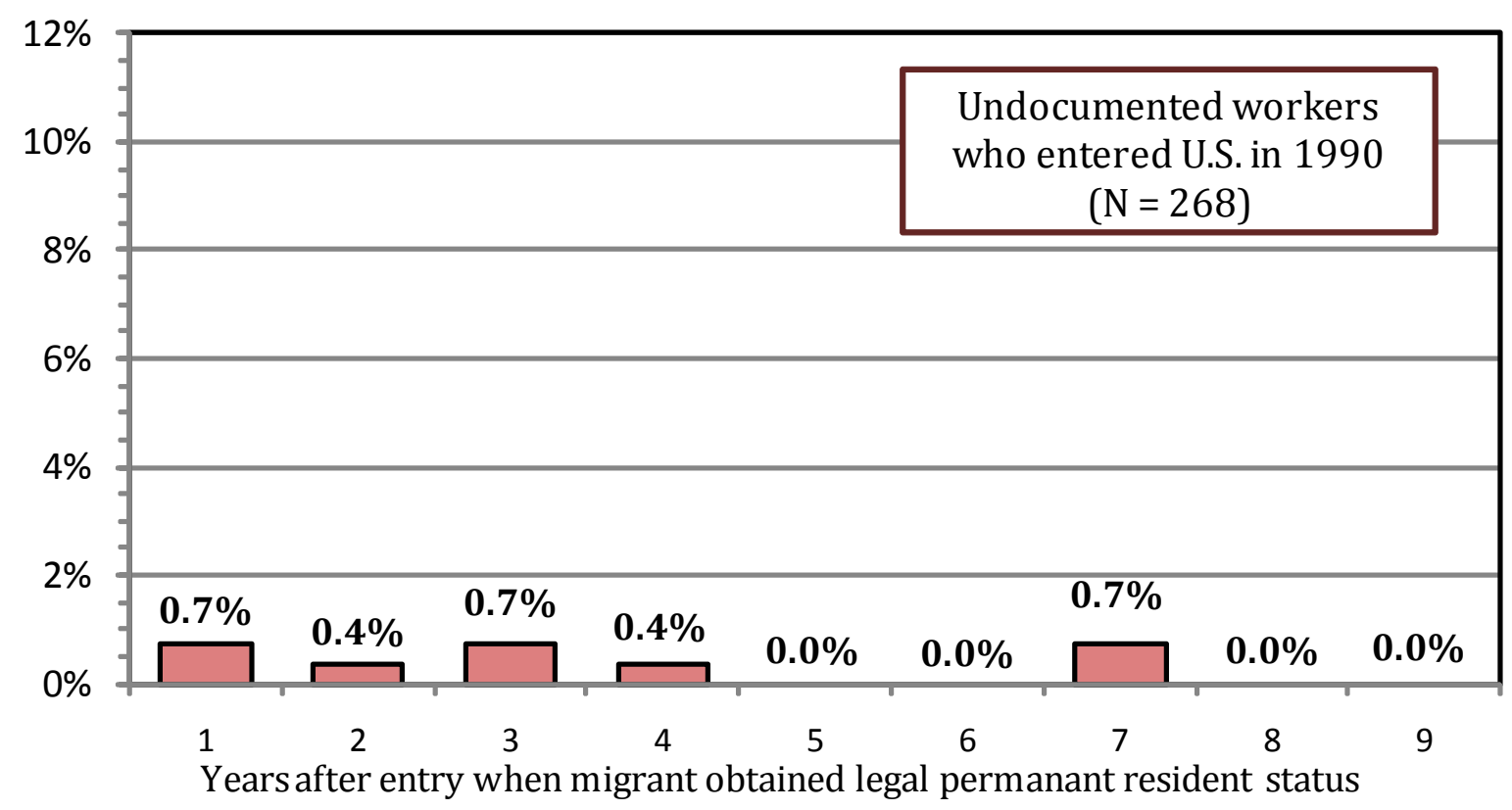

Source: Authors' tabulations of MMP files as explained in text. 


\section{CENTER FOR RETIREMENT RESEARCH AT BOSTON COLLEGE}

How Important Are Intergenerational Transfers for Baby Boomers?

Alicia H. Munnell, Anthony Webb, Zhenya Karamcheva, and Andrew Eschtruth, January 2011

Effect of Informal Care on Work, Wages, and Wealth

Courtney Harold Van Houtven, Norma B. Coe, and Meghan Skira, December 2010

Recessions, Wealth Destruction, and the Timing of Retirement

Barry P. Bosworth and Gary Burtless, December 2010

Measuring the Spillover to Disability Insurance Due to the Rise in the Full Retirement Age Norma B. Coe and Kelly Haverstick, December 2010

Is the Reduction in Older Workers' Job Tenure a Cause for Concern?

Steven A. Sass and Anthony Webb, December 2010

Accounting for Disability Insurance in the Dynamic Relationship Between Disability Onset and Earnings

Perry Singleton, November 2010

The Treatment of Married Women by the Social Security Retirement Program

Andrew G. Biggs, Gayle L. Reznik, and Nada O. Eissa, November 2010

What is the Impact of Foreclosures on Retirement Security?

Irena Dushi, Leora Friedberg, and Anthony Webb, November 2010

Children and Household Utility: Evidence from Kids Flying the Coop

Norma B. Coe and Anthony Webb, November 2010

Overview of the CRR 2009 Retirement Survey

Alicia H. Munnell, Norma B. Coe, Kelly Haverstick, and Steven A. Sass, October 2010

State Wage-Payment Laws, the Pension Protection Act of 2006, and 401(k) Saving Behavior

Gary V. Englehardt, October 2010

Asset Cycles and the Retirement Decisions of Older Workers

Jan Ondrich, October 2010

Price Deflators, the Trust Fund Forecast, and Social Security Solvency

Barry Bosworth, October 2010

All working papers are available on the Center for Retirement Research website (http://crr.bc.edu) and can be requested by e-mail (crr@bc.edu) or phone (617-552-1762 